\title{
Schoology Implementation in the Teaching of Production OralePréÉlémentaire
}

\author{
EviEviyanti $^{1}$ \\ \{eeviyanti@yahoo.com ${ }^{1}$ \} \\ Departement of French Language Education, Universitas Negeri Medan, Indonesia ${ }^{1}$
}

\begin{abstract}
The 21st century learning process requires the integration of Information and Communication Technology (ICT) in learning activities.The development of information and communication technology now requires the rapid development of learning needs.The concept of learning could be implemented with the help of technology, such as online learning media which is often called e-learning. E-learning is developed with a multimedia format that provides text, images, and learning videos. Therefore learning becomes more effective and enjoyable.The application of e-learning will be more practical and efficient in its use by using mobile devices, then mobile learning came up as a learning medium to make better education. The obstacles that often arise in the learning process are expected to be overcome by the existence of mobile learning. One of the media which could overcome the problem of learning in class is LMS (Learning Management System).LMS is a software for administration, documentation, online teaching and learning activities (on the network).Schoology is the right LSM to support learning activities in the teaching of Production Orale Pré Élémentaire (Speaking for beginners). Schoology is one of the Learning Management System applications that provide multimedia, video streaming, and interactive appearance in a variety of data format sizes. The LMS application has the main character, namely users who are instructors and students both connect to the internet. The form of LMS learning can be in the form of e-books, videos, web or blogs, and social networks. This application is a newcomer in the field of online learning. Schoology has a model like Facebook and has many advanced features in the design aspect. The fiture scan facilitate lecturers in making discussion questions, collaborative groups or possible assignments creation of interaction between students and lecturers. Lecturers can also participate in monitoring discussions held by students.
\end{abstract}

Keywords: E-learning, Schoology, Production OralePréÉlémentaire.

\section{Introduction}

Science development, information and communication technology that increase fast encourage renewal efforts in the utilization of technological results, especially in learning. One of the information and communication technology development characters in learning is the delivery of information increasing fast and accurate. Nowadays, the information technology development has been able to process, package, display and disseminate learning information, both audiovisual and multimedia.

This is supported by the existence of a computer as the main component and the availability of a network that is able to connect between one computer and another, even in 
international reach. For the world of education the development of technology is an effective innovation in the learning process that is implemented in web-based learning media.

According to Rusman (2013), web-based learning is a learning activity that utilizes mediasites (websites) that can be accessed through the internet network. Web-based learning or also known as "web based learning" is one type of application of electronic learning (elearning). According to Munir (2012), e-learning is an internet-based application program that contains all the information about clear, dynamic, and up-to-date education that makes it easy for learners to do online learning. The teaching and learning process that is usually done in class can be done through the internet outside the classroom without having to face to face. Currently e-Learning is increasingly known as one of the ways to overcome the problem of education, both in developed and developing countries.

E-learning implementation will be more practical and efficient in its use by using mobile devices. Then comes mobile learning as a learning medium to advance the world of education. Through mobile learning, it is expected that the obstacles that often arise in the learning process can be overcome. Mobile learning is unique learning because every student can access learning material anytime and anywhere.

One of the supporting media that can overcome the problem of learning in class is LMS (Learning Management System). The existence of LMS is expected to improve student learning outcomes as students. LMS is a software for administration, documentation, an activity report, training materials, and all teaching and learning activities are done online. One of the LMS that can be used in the Production Orale Pré Élémentaire teaching is schoology.

Schoology is an application of Learning Management System (LMS) through a combination of multimedia, video streaming, and interactive appearance in a variety of standard and smaller size data formats. The LMS application has the main character, namely users who are instructors and students both connect to the internet. The form of LMS learning can be in the form of e-books, videos, web or blogs, and social networks.

\section{Teaching Of Production Orale Pré Élémentaire Using Schoology Learning Media}

In the teaching and learning process, there are two important elements that are interconnected, namely learning methods and learning media. Determination of a good learning method through the lecturer will affect the determination of thelearning media that will be used to fit the learning method.

According to Susilana and Riyana (2009) the media is an introduction or intermediary. Whereas according to Heinich in (Susilana and Riyana, 2009) the media is a communication channel tool. So, Media is all forms and channels used to convey information or messages.

E-learning according to Darmawan (2014) is a combination of two electronic and learning words which means electronic learning. E-learning or electronic learning was first introduced by the University of Illinois at Urbania-Campaign by using a computer-based instruction system and a computer called Plato. E-learning according to Henderson (2003), namely:

E-learning is learning at a distance that uses computer technology (usually the Internet). E-learning enables employees to learn at their work computers without traveling to a classroom. E-learning can be a scheduled session with an instructor and other students, or it can be an on-demand course that the employee can take for self-directed learning at a time when it's convenient. 
Based on some of the opinions above, e-learning is an internet application that can connect between lecturers and students in online classes. E-learning with a class has the same position as conventional classes in universities. Understanding the same or equal position means that these electronic classes can replace classes in the existing universities. Not only as a complement to existing colleges. The educational process runs at any time and can shorten the learning time target and save costs that must be incurred by an educational institution (school, college).

E-learning is learning form that integrates learning processes from traditional learning, online learning, and a combination of various other learning models, one of which is blended learning. The blended learning model is a combination of online technology and face-to-face learning in class.

E-Learning has advantages and disadvantages as a learning medium. According to Soekartawi, Mulvihil, Utarini in Rusman (2013) states that the instructions on the benefits of distance education (the advantages of E-Learning), among others: (1) the availability of emoderating facilities where lecturers and students can communicate easily through internet facilities on a regular basis or whenever the communication activity is carried out without being limited by distance, place and time, (2) lecturers and students can use structured andscheduled instructional materials or instruction through the internet, so that both can assess each other to how far the teaching material is learned, (3) students can learn or review material at any time and anywhere needed, given the teaching materials stored on the computer, (4) if the students need additional information related to the teaching material they learn, can access the internet more easily, (5) both lecturers and students can conduct discussions via the internet which can be followed by a large number of participants, thus increasing knowledge and broader insight, (6) changing the role of students from those who are usually passive to being active and more independent, and (7) relatively more efficient, for example those who live far from school or college. However, the use of the internet for learning or e-learning has disadvantages too. Some of the criticisms raised by Bullen, Beam in Rusman (2013) include (1) the lack of interaction between lecturers and students or even between students themselves. This lack of interaction can slow the formation of values in the learning process, (2) the tendency to ignore the psychomotor aspects or social aspects and instead encourage the growth of business / commercial aspects, (3) the learning process tends towards training rather than education, (4) the changing role of the lecturer from mastering conventional learning techniques, are now required to know learning techniques that use ICT, (5) students who do not have high learning motivation tend to fail, (6) not all places are available internet or network facilities, (7) lack of staff who know and have the skills to operate internet, and (8) lack of understanding about mastering computer programming languages.

In the process of learning the Production Orale Pré Élémentaire which has a weight of 3 credits, the lecturer is required to be able to use innovative and creative learning media in accordance with the development of technology and communication science. Production Orale Pré Élémentaire courses are taught to students in semester I. Therefore, one of the learning media used is e-learning media by using Schoology as a learning medium that might help an effective learning process. This media is expected to motivate students to speak French at the beginner level.

Understanding Schoology according to Aminoto and Pathoni (2014) is a website that combines e-learning and social networking. The concept is the same as Edmodo, but Schoology has many advantages. Building e-learning with Schoology is also more profitable 
when compared to using moodle, because it does not require hosting andmanaging Schoology (more user friendly). Of course the features are not as complete as moodle, but for e-learning learning in Higher Education is very adequate. The features that Schoology are as follows: Courses, Group, Discussion, Resources, Quiz, Attendance, and Analytics.

Schoology's home appearance can be displayed in the picture below,
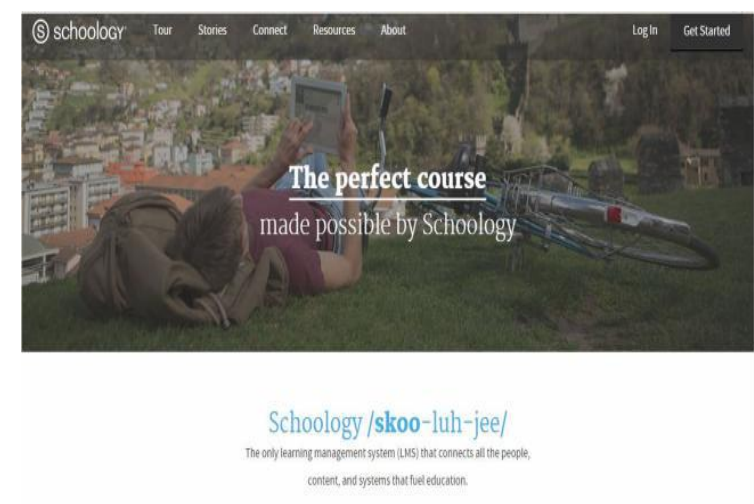

Figure 1. Home Appearance of Schoology

(www.schoology.com)

There are three ways to log in to Schoology account, including:

a. Basic, consists of:

1. Instructor, sign up for Schoology account owners.

2. Students, need an access code provided by the lecturer.

3. Parents, need an access code provided by the lecturer.

b. Enterprise, for an institution or school that manages lecturers andlearning with functional and administrative education.

At the login stage to schoology account, lecturers, students, and parents must log in.

The Schoology login view can be displayed in the following Figure 


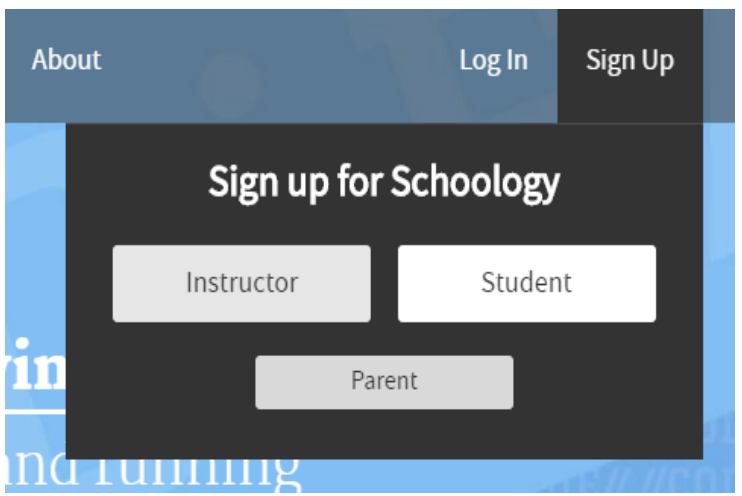

Figure.2. Schoology Login View (www.schoology.com)

The menu contained in the Schoology application include:

a.Courses, through courses menu, users can create new classes, join classes that have already been there or browse through list of classes that have been set. In this feature the lecturer gives the class name Production OralePréÉlémentaire course.

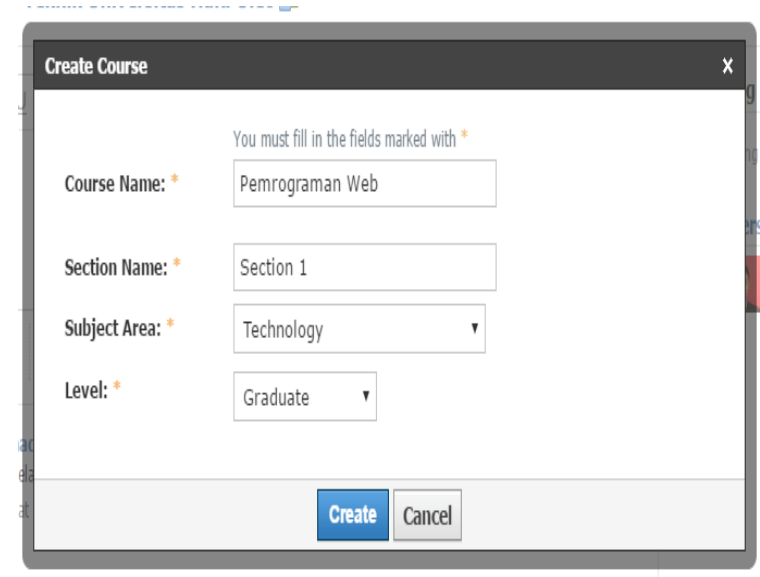

Figure.3.Menu courses (www.schoology.com)

The facilities used as learning supplements are Courses which consist of discussion, Test, and Quiz. 


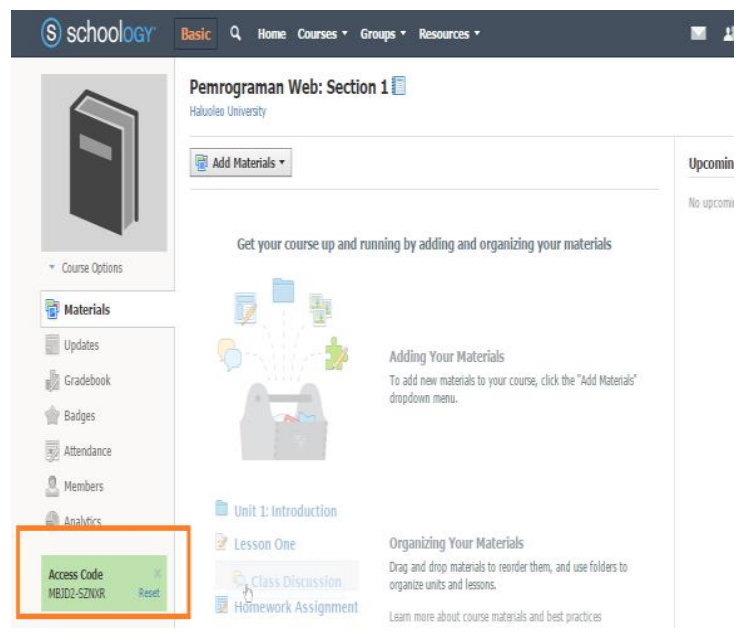

Figure 4. The Example of the Class code in the lower left corner (www. Schoology.com)

In this feature code access will appear. Access to the code must be informed to students as college participants and their parents so that communication between lecturers and students in the learning process can run well. Furthermore, parents can also monitor the progress of their children's lectures and communicate with the lecturer who teaches the subject. Lecturers, students and parents can discuss online (in the network) anytime and anywhere.

a.Groups, functions like wall messages where group members can alsopost wall messages. When joining a group, users canlook for the part of the group that the user wants.

b.Resources, to maintain, track documents, files, and images that usersupload in class.

In the Resources menu facility (learning source) that isdiscussion, as an assignment for students, Test as a matter of practice and Quizas a test of understanding of material or competency tests. After facilitating the menuResources, e-learning will be obtained with Schoology as a supplementlearning that can take Production Orale Pré Élémentaire courses used as learning innovations for professors and students instudy the "se présenter" material.If the lecturer wants to assign assignments to students then click select thetype of materials Assignment. 


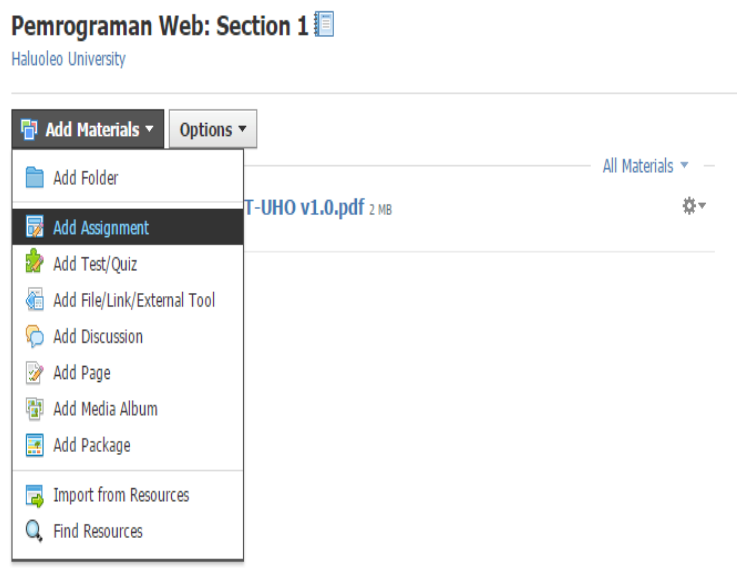

Figure.5. Assigning the Assignments (www. Schoology.com)

For example is the lecturer assigns students to create dialogues with the theme "se présenter" in groups. Each group consists of 3 people. Their dialogue must be recorded in the form of a video. The dialog and video recordings that have been made by students must be uploaded to Schoology in accordance with the date and time of collection of tasks that have been determined by the lecturers. So that the lecturer can assess the discipline and responsibility of students. Then the lecturer can listen, see and assess the ability to speak French every student online. Even students' parents can also see the development of their children's ability to speak French anywhere and anytime.

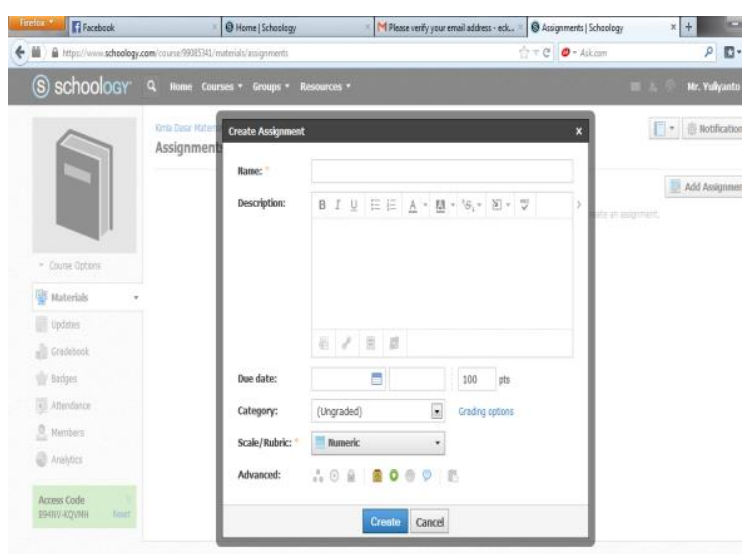

Figure.6. Assignments Add Assignments Task Content (www.schoology.com)

\section{Explanation:}

Due date : The End Date

Time :Slowest time

Scale/Rubric :Evaluation Scale 
a.Recent Activity, to display the latest news contained in the accountSchoology. Lecturers can post and update in the account as wellchoose which page the user will post.

b.Calendar, to display the calendar page that has been postedpreviously in Recent Activity.

c.Messages, to send messages or see messages between peopleSchoology users. For example, the lecturer provides information to studentsabout face-to-face meetings in class. Students must discuss andidentify pronunciation of vowels and consonants in Frenchbased on the material in the learning video that they downloaded earlier.

d.People, to be able to see a list of users in a class.

Lecturers have implemented one of the e learning learning models namely blended learning in the learning process of the Production OralePréÉlémentaire course. In the learning process the lecturer uses e-learning learning media "Schoology" and face to face in class. Combining the learning process between face to face and online is called blended learning. According to Darmawan (2014) blended learning is a combination of various learning models aimed at optimizing the process and learning services both distance, traditional, media, and even computer-based. Furthermore Azad (2013) argued that blended learning is:

Blended learning is a blending of different learning methods, techniques and applying them in an interactively meaningful learning environment. Learners should have easy access to different learning resources in order to apply the knowledge and skills they learn under the supervision and support of the teacher inside and outside the classroom.

According to Rovai and Jordan (2004), Blended learning is a blended learning model is basically a combination of learning excellence that is done face-to-face (face to face learning) and virtually (e-Learning).

Based on some of the opinions above, blended learning is a combination of face-to-face and online learning (in the network) to optimize the learning process. Through the blended learning model, the learning process will be more effective because the teaching and learning process that is usually done (conventional) will be assisted through e-learning (schoology) supported by information technologythat has developed rapidly and can be done anytime and anywhere.

\section{Conclusion}

Schoology is a learning system (LMS) that has been well designed based on the web (web-based tool). This application is a newcomer in the field of online learning. Schoology has a model like Facebook and has many advanced features in the design aspect. The fiture scan facilitate lecturers in making discussion questions, collaborative groups or possible assignments creation of interaction between students and lecturers. Lecturers can also participate in monitoring discussions held by students. Another aspect that Schoology has is that it can provide academic information to students. Students can access their values, attendance records, and lecturer feedback on the electronic assignments submitted. Parents can also find out directly about the development of their children's learning outcomes. Lecturers and parents can communicate through Schoology.

Lecturers must be able to use innovative and creative learning media in accordance with the development of technology and information science, for example "Schoology". The 
learning process by using Schoology learning media can be carried out at any time and anywhere by using a smartphone, laptop, or computer connected to the internet network.

\section{References}

[1]Aminoto, Tugiyo dan Pathoni, Hairul.: Penerapan Media E-Learning Berbasis Schoology untuk Meningkatkan Aktivitas dan Hasil Belajar Materi Usaha dan Energi di Kelas XI SMA N 10 Kota Jambi. Jurnal Pendidikan Fisika. Jambi: Universitas Jambi. Vol. 8 No. 1, 14-29 (2014)

[2]Azad, Rakesh.: Blended Learning: A Way For Excellence In Teacher Education In EWorld.[Online]. International Journal Proceeding of the Global Summit on Education ,Volume. 3, No.1, Available:http://www.WorldConferences.net [7th of December 2015]. (2013)

[3]Darmawan, Deni.: Pengembangan E-Learning Teori dan Desain. PT Remaja Rosdakarya, Bandung (2014)

[4]Henderson, Allan J.: The E-Learning Question and Answer Book. American Management Association, Inc, New York (2003)

[5]Munir.: Pembelajaran jarak jauh. Alfabeta, Bandung (2012)

[6]Rusman.: . Belajar dan Pembelajaran Berbasis Komputer: Mengembangkan Profesionalisme Guru Abad 21. Alfabeta, Bandung (2013)

[7]Rovai, A.P., Jordan, H.M.: Blended learning and sense of community: a comparative analysis with traditional and fully online graduate courses.[Online]. Journal International Review of Research in Open and Distance $=$ Learning, Volume 5, No. Available:http://www.irrodl.org/index.php/irrodl/article/viewFile/192/795.com (2004)

[8]Siemens, George, A.: A Learning Theory for the digital Age.(Online), (http://www.elearnspace.org/Articles/connectivism.html) (2004)

[9]Susilana, R. \& Riyana, C.: Media Pembelajaran. CV Wacana, Bandung (2009)Prima.www.Schoology.com 